\title{
Contamination Assessment of Underground Water Around a Cemetery: Case study of Ayobo cemetery in Lagos, Nigeria.
}

\author{
Alagbe Edith Egbimhanlu ${ }^{1 *}$, Okocha Dumebi Sophia ${ }^{1}$, Ayegbo Stephen Korede ${ }^{2}$, Oyeniyi Esther Adenike ${ }^{1}$, Alagbe \\ Olusegun Adegboyega ${ }^{3}$, Daniel Ebakota Omonigho ${ }^{4}$, Efeovbokhan Vincent Efeovbokhan ${ }^{1}$ \\ ${ }^{I}$ Department of Chemical Engineering, Covenant University, Ota. Nigeria. \\ ${ }^{2}$ Department of Civil Engineering, Covenant University, Ota. Nigeria. \\ ${ }^{3}$ Department of Physical Planning permit Authority, Ikeja. Nigeria. \\ ${ }^{4}$ Department of Microbiology, Benson Idahosa University, Benin city. Nigeria.
}

ORCID No.:0000-0002-0533-9789

\begin{abstract}
Water quality monitoring is essential for continual availability of safe water for both domestic and industrial use. This work serves to identify potential risks from underground water sources sited around burial sites and also, to provide the initial data on the impact of such toxins on the water quality and the environment. Samples from 9 points ( 7 bore hole outlet and 2 dug wells) were taken within 500 metres circumference from Ayobo cemetery in Lagos, Nigeria and analysed for their physico-chemical properties using standard procedures. Results revealed that samples majorly had high salinity $(5.5 \pm$ $1.9)$, slightly acidic $\mathrm{pH}$ values $(5.23 \pm 0.94)$ and significantly elevated lead concentrations $(0.63 \pm 0.27)$ among the parameters measured. This acidity makes the water more vulnerable to metals dissolving in it. It is unclear if the sources of the salts are from the soil itself and/or compounds used for preparing the corpse for burial or the metal fittings and paints used in the finishing of the caskets being contributory to the lead contamination. This work forms the initial water quality for the Ayobo axis but more work is recommended to ascertain the precise source of these contaminants while initial water quality assessment should be carried out and documented before future cemeteries are sited. A regular monitoring and the use of buffers to neutralize the acidic water are recommended.
\end{abstract}

Keywords: Aquifer, Borehole, Cemetery water, Hand-dug wells, Lead poisoning, Underground water.

\section{INTRODUCTION}

Groundwater is essential for life both for domestic and industrial use. Water is a ready resource for both crop and animal farming. In cities, asides domestic uses, groundwater is used to water crops in gardens and small farms around the home and a major source of water for fish farmers. Urbanization has its effect on the quantity and quality of underground water [1]. A cemetery is an allotted piece/expanse of land that is wholly dedicated to the disposal of human corpses. Cemeteries were initially located very far from residential areas but increase in population and urban migration has now made the cemeteries to be part of our residential areas. In Esanland in South-South Nigeria and a majority of other tribes, the dead adults are buried within their compounds [2]. Over time, the materials (metals, wood, chemicals) would degrade beneath the surface and gradually leach into our underground water systems [3, 4]. The leaching process may be slow but it is certain to happen.

Ayobo is a suburb in Alimosho local Government Area in Lagos State, Nigeria. The cemetery, just like other cemeteries, was situated away from residential areas but daily urban influx into Lagos city has made Lagos state witness development into lands earmarked for activities like burial grounds. This encroachment makes it paramount for a quick monitoring and regular/periodic checks on the water quality in and around the cemeteries. The cemetery covers an area of about 17,344 sq.m and it is about 7 years old [5]. Each tomb accommodates at least one body but family tombs may contain more than one body. There are about 512 visible tombs in the cemetery (representing about 700 buried corpses) and this covers about $3 / 4$ of the land space.

The quality of water is described by its physical, chemical and biological contents $[6,7]$. The effects of water contamination may be aesthetic (with respect to colour, taste and odour), cosmetic (causing skin or tooth discoloration) or technical (causing damage to water equipment or hampering treatment for other contaminants). These contaminants pose health hazards to consumers of the water from the underground sources [8]. Previous work of Soladoye and Ajibade (2014) [9] revealed that most hand-dug wells in Lagos state fell short of both national and international standards for drinking water. Most samples were acidic and had metal contaminants of Magnesium, Manganese and Zinc at varying levels. Olowu, 2019 [10] reported the water quality of the hand-dug wells, whose average depth range from $6-20$ metres, had average levels of $0.58 \mathrm{mg} / \mathrm{L}(\mathrm{NO} 3), 56 \mathrm{mg} / \mathrm{L}(\mathrm{Cl}), 4.0 \mathrm{mg} / \mathrm{L}(\mathrm{Mg})$, $0.02 \mathrm{mg} / \mathrm{L}(\mathrm{Fe}), 0.02 \mathrm{mg} / \mathrm{L}(\mathrm{Mn})$ and $1.05 \mathrm{mg} / \mathrm{L}(\mathrm{Zn})$. On the other hand, results of water quality supplied to the Ayobo axis by the Lagos State water Corporation have values within the 
national and international standards, with average values of $9.0 \mathrm{mg} / \mathrm{L}(\mathrm{Ca}), 0.23 \mathrm{mg} / \mathrm{L}(\mathrm{Fe}), 12 \mathrm{mg} / \mathrm{L}(\mathrm{Mg}), 16.9 \mathrm{mg} / \mathrm{L}(\mathrm{Cl})$ and very low microbial presence [11]. Unfortunately portable water supply is grossly inadequate and often times irregular. This has forced residents to become self-reliant by providing water for themselves via bore holes and hand-dug wells, to meet domestic needs.

Land-use practices have been found to impact underground water quality $[12,13]$. Water contamination is known to also, be induced by leakages from septic tanks, cemeteries and underground storage systems [14] or waste disposal sites [15]. Cemeteries are considered a major threat to groundwater quality because of the perceived microbial activities that goes with decaying corpses [16]. Heavy microbial loads have been reported in and around some areas like, the Varzea cemetery [17] vasconceles+2006; ThasantoAmaro cemetery [18];

A majority of urban population in Lagos metropolis and its suburb sink personal bore holes while few still draw water from dug wells - within their compounds. It has been reported that about $60 \%$ of the Nigerian population access underground water for sustenance [19]. The water quality from these sources are neither measured at the inception, nor monitored over time. Therefore, the aim of this work is to assess/identify potential threats of contamination from the burial grounds and to also provide the initial level of contamination of the underground water in and around Ayobo cemetery.

\section{METHODLOGY}

\section{Study Area}

The research area was around Ayobo cemetery which is situated on a fairly upland while the West (W) and East, E are higher in topography. The land slopes steeply to the North of the reference point while the South is at the same level of the cemetery. There are no tarred roads around the axis and the cemetery itself is unfenced. Water samples were collected from taps (of sunk bore holes) and open wells within $500 \mathrm{~m}$ circumference from the entrance of the cemetery which was taken as the starting point for all sample collection. Table 3 (Appendix A) shows the approximate distance between points of sample collection

\section{Sample collection}

Samples were collected from 9 locations (labelled Point $1-9$ ) within $500 \mathrm{~m}$ circumference from the entrance of the cemetery (which was taken as the starting point) inside sterilized $2 \mathrm{X} 1 \mathrm{~L}$ PET bottles per location and stored in a refrigerator at a temperature of $4{ }^{0} \mathrm{C}$ till the following day for analysis. Analyses of samples were carried out within 24 hours of sample collection. See Fig. 1 (Appendix A) for map showing the points of sample collection.

\section{Physicochemical analyses of water}

Physical parameters like temperature (T), pH, Salinity, Total Suspended Solids (TSS) and Turbidity were measured using the Hanna Instrument Water proof Tester while the analysis for Calcium ( $\mathrm{Ca}$ ), Iron (Fe), Manganese (Mn), Magnesium $(\mathrm{Mg})$, Chlorides $\left(\mathrm{Cl}^{-}\right)$, Copper $(\mathrm{Cu})$, Nitrates $\left(\mathrm{NO}_{3}{ }^{-}\right)$were carried out using the Palintest Photometer. Standard procedures for Cadmium, $\mathrm{Cd}$ and Lead, $\mathrm{Pb}$ analysis were employed using the Atomic Absorption Spectrometer (AAS) [20].

\section{Bacteriological analysis}

The Chemical Oxygen Demand, COD and Biological Oxygen demand, BOD were analysed using standard methods for water and waste water analysis [21].

\section{Standards and control sample}

Results obtained were compared to threshold values of the World Health Organization (WHO) while the control was data of water sample supplied by the Lagos State Water Corporation to Ayobo and monitored by the Lagos state Water regulatory Board.

\section{RESULTS AND DISCUSSION}

Table 1: Results of the physical analysis of the water samples

\begin{tabular}{|c|c|c|c|c|c|}
\hline & TEMP, ${ }^{\circ} \mathrm{C}$ & $\mathbf{P H}$ & $\begin{array}{c}\text { Salinity, } \\
\mathbf{p p t}\end{array}$ & $\begin{array}{c}\text { TSS, } \\
\text { grams }\end{array}$ & $\begin{array}{c}\text { Turbidity, } \\
\text { NTU }\end{array}$ \\
\hline $\begin{array}{c}\text { STD/ } \\
\text { SAM } \\
\text { PLE }\end{array}$ & Ambient & $\mathbf{6 . 5 - 8 . 5}$ & $\mathbf{1}$ & $\mathbf{1}$ & $\leq \mathbf{5}$ \\
\hline 1 & 25 & $5.01 \pm 0.001$ & $4.27 \pm 0.01$ & $1 \pm 0.01$ & $2 \pm 0.21$ \\
\hline 2 & 24 & $7.28 \pm 0.001$ & $8.22 \pm 0.01$ & $2 \pm 0.01$ & $6 \pm 0.20$ \\
\hline 3 & 20.5 & $4.56 \pm 0.001$ & $5.83 \pm 0.01$ & $1 \pm 0.01$ & $3 \pm 0.20$ \\
\hline 4 & 21.6 & $5.14 \pm 0.001$ & $8.14 \pm 0.01$ & $1 \pm 0.01$ & $2 \pm 0.20$ \\
\hline 5 & 21.3 & $5.08 \pm 0.001$ & $4.13 \pm 0.01$ & $1 \pm 0.01$ & $10 \pm 0.52$ \\
\hline 6 & 25.5 & $5.02 \pm 0.001$ & $4.9 \pm 0.01$ & $1 \pm 0.01$ & $3 \pm 0.48$ \\
\hline 7 & 24 & $4.81 \pm 0.002$ & $3.92 \pm 0.01$ & $1 \pm 0.01$ & $4 \pm 0.38$ \\
\hline 8 & 22.4 & $4.84 \pm 0.001$ & $2.96 \pm 0.01$ & $1 \pm 0.01$ & $3 \pm 0.42$ \\
\hline 9 & 26.9 & $5.32 \pm 0.001$ & $7.78 \pm 0.01$ & $1 \pm 0.01$ & $2 \pm 0.22$ \\
\hline & & & & & \\
\hline Total & 211.2 & 47.06 & 50.15 & 10 & 35 \\
\hline Mean & $23.47 \pm 2.03$ & $5.23 \pm 0.94$ & $5.57 \pm 1.9$ & $1.11 \pm$ & $3.89 \pm 3.14$ \\
\hline
\end{tabular}

Table 1 reveals slightly acidic water in all samples except sample (2) which is almost neutral. The limitation of acidic medium is that it helps to promote the solubility and mobility of metal ions in water [22,23]. The water supplied to the area by the LSWC also has a slightly acidic pH of 5.53.

All water samples were found to be saline, as shown in Table 1. This high salinity in the water, leads to a rise in building and maintenance costs of structures, like roads and pipes, due to damage from the saline water [24]. On plants, high salinity may force the occurrence of reverse osmosis where the water in the roots of plants migrates into the underground water. Plant growth is stunted in most crops and the resulting effect is a drop in the crop yield as reported in France, Netherlands 
International Journal of Engineering Research and Technology. ISSN 0974-3154, Volume 13, Number 6 (2020), pp. 1283-1288

(C) International Research Publication House. https://dx.doi.org/10.37624/IJERT/13.6.2020.1283-1288

and Italy by $[25,26]$.

The turbidity of all samples, as shown in Table 1, was in order except for samples (2) and (5) whose levels were far higher than the recommended level. Turbidity may be an indication of microbial presence in the water which is corroborated by the high BOD value of samples (2) and (5) (from Table 2).

Table 2: Results of the chemical analysis of the water samples

\begin{tabular}{|c|c|c|c|c|c|c|c|c|c|c|c|}
\hline LOCATIONS & $\mathrm{Ca}, \mathrm{mg} / \mathrm{L}$ & $\mathrm{Fe}, \mathrm{mg} / \mathrm{L}$ & $\mathrm{Mn}, \mathrm{mg} / \mathrm{L}$ & Mg & $\mathrm{Cl}, \mathrm{mg} / \mathrm{L}$ & $\mathrm{Cu}, \mathrm{mg} / \mathrm{L}$ & NO3, mg/L & $\mathrm{Cd}, \mathrm{mg} / \mathrm{L}$ & $\mathrm{Pb}, \mathrm{mg} / \mathrm{L}$ & BOD, $\mathrm{mg} / \mathrm{L}$ & $\mathrm{COD}, \mathrm{mg} / \mathrm{L}$ \\
\hline STD/SAMPLE & 100 & 0.3 & 0.05 & 30 & 100 & 2 & 11 & 0.03 & 0.01 & $1-5$ & NIL \\
\hline 1 & $15 \pm 0.01$ & $0.03 \pm 0.01$ & $0.03 \pm 0.1$ & $20 \pm 0.011$ & $1.4 \pm 0.01$ & $0.38 \pm 0.005$ & $0.492 \pm 0.01$ & $0.003 \pm 0.01$ & $0.71 \pm 0.01$ & $1.4 \pm 0.02$ & $244 \pm 0.01$ \\
\hline 2 & $61 \pm 0.01$ & $0.06 \pm 0.05$ & $0.00 \pm 0.11$ & $19 \pm 0.011$ & $0.5 \pm 0.01$ & $0.32 \pm 0.036$ & $0.449 \pm 0.01$ & $0.015 \pm 0.12$ & $0.7 \pm 0.01$ & $30 \pm 0.02$ & $248 \pm 0.01$ \\
\hline 3 & $45 \pm 0.01$ & $0.03 \pm 0.012$ & $0.005 \pm 0.21$ & $9 \pm 0.015$ & $1.7 \pm 0.01$ & $0.04 \pm 0.027$ & $0.457 \pm 0.01$ & $0.05 \pm 0.04$ & $0.04 \pm 0.011$ & $5 \pm 0.02$ & $132 \pm 0.01$ \\
\hline 4 & $25 \pm 0.01$ & $0.03 \pm 0.012$ & $0.009 \pm 0.23$ & $21 \pm 0.016$ & $1.2 \pm 0.01$ & $0.16 \pm 0.025$ & $0.635 \pm 0.01$ & $0.022 \pm 0.04$ & $0.5 \pm 0.011$ & $2.3 \pm 0.02$ & $232 \pm 0.04$ \\
\hline 5 & $11 \pm 0.01$ & $0.04 \pm 0.014$ & $0.004 \pm 0.28$ & $20 \pm 0.014$ & $1.6 \pm 0.01$ & $0.1 \pm 0.028$ & $0.309 \pm 0.01$ & $0.015 \pm 0.52$ & $0.83 \pm 0.012$ & $30 \pm 0.012$ & $312 \pm 0.01$ \\
\hline 6 & $12 \pm 0.01$ & $0.04 \pm 0.01$ & $0.027 \pm 0.24$ & $5 \pm 0.014$ & $1.2 \pm 0.01$ & $0.18 \pm 0.032$ & $0.55 \pm 0.01$ & $0.008 \pm 0.43$ & $0.76 \pm 0.012$ & $1.4 \pm 0.02$ & $204 \pm 0.01$ \\
\hline 7 & $3 \pm 0.01$ & $0.01 \pm 0.011$ & $0.001 \pm 0.33$ & $7 \pm 0.015$ & $1.9 \pm 0.01$ & $0.1 \pm 0.022$ & $0.348 \pm 0.01$ & $0.007 \pm 0.44$ & $0.76 \pm 0.011$ & $2.2 \pm 0.02$ & $80 \pm 0.02$ \\
\hline 8 & $2 \pm 0.01$ & $0.03 \pm 0.01$ & $0.005 \pm 0.1$ & $24 \pm 0.016$ & $0.7 \pm 0.01$ & $0.18 \pm 0.025$ & $0.347 \pm 0.01$ & $0.015 \pm 0.52$ & $0.39 \pm 0.011$ & $2.4 \pm 0.02$ & $392 \pm 0.01$ \\
\hline 9 & $9 \pm 0.01$ & $0.04 \pm 0.01$ & $0.021 \pm 0.20$ & $13 \pm 0.014$ & $1.3 \pm 0.01$ & $0.18 \pm 0.022$ & $0.55 \pm 0.01$ & $0.004 \pm 0.46$ & $1.01 \pm 0.011$ & $4.4 \pm 0.02$ & $52 \pm 0.01$ \\
\hline Total & 183 & 0.31 & 0.1 & 138 & 11.5 & 1.64 & 4.14 & 0.14 & 5.7 & 79.1 & 1896 \\
\hline Mean & $20.33 \pm 18.976$ & $0.03 \pm 0.01$ & $0.01 \pm 0.01$ & $15.33 \pm 6.55$ & $1.28 \pm 0.43$ & $0.18 \pm 0.10$ & $0.46 \pm 0.46$ & $0.02 \pm 0.01$ & $0.63 \pm 0.27$ & $8.79 \pm 11.4$ & $210.67 \pm 102.52$ \\
\hline
\end{tabular}

WHO STD $=$ World Health Organization Standard

LSWC STD = Lagos State Water Corporation Standard

$\mathrm{ND}=$ Not Determined

From Table 2, it was observed that most metal contents where within acceptable limits but the presence of Lead $(\mathrm{Pb})$ in all water samples was at least, $400 \%$ above the minimum acceptable level which is contrary to findings in water contaminated by abattoirs [27]. However, this result is in consonance with findings of [28,29]. Unfortunately, the analysis done by the Water Regulatory Board of Lagos State did not cover the Lead level, for comparison. We may assume that a contributory source of lead is probably, the brass fittings and paints used for improving the aesthetics of the caskets (in the case of leaching into the underground water has ben initiated), coupled with plumbosolvent nature of acidic water [30]. Landmeyer et al (2003) [31] suggests that lead contamination may also have come from the local aquifer material. Lead is generally undesirable in drinking water because even in very low levels, it can cause problems in the growth and development of children. These challenges range from slowed growth to depressed learning ability and low intelligence quotient (IQ).

Cadmium levels were within the limits specified by WHO except in Sample (3) and this result is similar to that reported in portable water in Warri, Nigeria by [32]. High Cadmium levels were however found in Japan waters which resulted in many cases of osteoporosis in water contaminated in Japan [33].

The BOD values of most samples were within permissible range. The $\mathrm{BOD}$ is indicative of the amount of oxygen which bacteria present in the water would consume while decomposing organic matter. High BOD observed in samples (2) and (5) are above recommended levels. Water with high BOD is unfit for drinking and in Nigeria where there are still reports of outbreaks of water borne diseases, the siting of wells or boreholes near cemeteries may be a contributing factor as reported by Gerba and Bitton (1984) [34] and De Ville de Goyet (1980) [35]. Low humidity which characterizes the climate in Nigeria may not be favourable to the boost of surface bacteriological contamination, as opposed to the findings of Rodriguez and Pacheco (2010) [36]. The low BOD load may suggest that the water table is deep enough to escape invasion by pathogens $[37,38]$ but may be close enough to the Sea level to allow seepage of Sea water to impact on the salinity. Our results of low BOD results are in consonance with the results found in the Domini Max II cemetery, in the Belem region in Para State [39] and the contemporary cemetery at da Paz in Sao Paulo [40]. Abia et al (2018) [41] reported that surface soils up to $2 \mathrm{~m}$, contained a high level of human disease functional group; antibiotic and resistance and drug synthesis signatures were also present and identified in the samples.

Formaldehyde, which is used in the preservation of the corpse, is generally not a threat to underground water contamination because the chemicals released after burial and ensuing decomposition, are inert. The only concern is on the handlers of formaldehyde (mortuary attendants) who are exposed to it. [42].

Unfortunately, ground water always looks clear because the layers of soil are natural filters for the water. However, the clarity is no guarantee of being safe for human consumption. 
Therefore, a regular monitoring of underground water is necessary to observe the demand and pollution level of underground water [43]. High presence of ions and salts in water is undesirable as it leads to water-borne diseases (8).

Seepages from the cemeteries result from the decaying bodies [44], burial materials and other matters [45,46]. Planting of trees and border plants around the vicinity of cemeteries, have been prescribed to help curb and/or control the transport of microorganisms (viruses and bacteria) in water and rain water seepage (44).

\section{CONCLUSION}

Results obtained from the physico-chemical and biological analyses of water samples from sources around the Ayobo cemetery revealed some analysed parameters (especially Lead and salinity) exceeded the limits prescribed by WHO. Contaminated water, which comes as metal or microbial loads, is injurious to both human health and plant/aquatic life. As at now, this research work does not affirm that the cemetery is responsible for the present level of contamination but serves as the premier reference data for underground water around the cemetery. Since population increase and urbanization do not favour the proper siting of cemeteries these days and also, the slow but inevitable leaching of the bodies and burial materials, it is imperative that the water in areas around the cemeteries be monitored and adequate measures put in place to quickly and efficiently manage any disruption that may appear in the water quality. This would ensure that it is safe and beneficial to health. Considerations for well managed cemetery with suitable soil condition and drainage arrangement are recommended for future siting of cemeteries.

\section{ACKNOWLEDGEMENTS}

The Team would like to specially thank the Management of Covenant University for financial support in publishing this article. We also thank Benson Idahosa University and the Lagos State Ministry of Physical Planning for support in providing an enabling environment for this research with Covenant University.

\section{CONFLICT OF INTEREST}

All authors declare no competing interest, as far as this work is concerned.

\section{REFERENCES}

[1] Foster, D., Hirata, R., "Groundwater Pollution risk assessment: a Methodology using available data". PAHO-CEPIS. 1998, pp. 13-15.

[2] Zume, J. T., "Assessing the potential risks of burial practices on groundwater quality in rural north-central Nigeria". 3, Sept 2011, J Water Health, Vol. 9, pp. 60916.
[3] Eni, D. I., Obiefuna, J. N., Oko, C., Ekwok, I., "Impact of urbanization on sub-surface water quality in Calabar municipality, Nigeria". 10, 2011, International Journal of Humanities and Social Science, Vol. 1, pp. 167-172.

[4] Ojewumi, M. E., Anenih, V. E., Alagbe, E. E., Oyeniyi, E. A., "Kinetic studies of biologically remediated crude oil polluted soil using a bacteria and fungi". 2019, J. Phy: Conf Ser., Vol. 1299 012001, pp. 1-13.

[5] Report on the siting of Ayobo Cemetery. Lagos State Ministry of Physical Planning and Development. 2010.

[6] Diersing, N., "Water Quality: frequently Asked questions". PDA, NOAA, 2009.

[7] Olukanni, D. O., Alatise, M. O., "Rainfall-Runoff Relationships and Flow Forecasting, Ogun River, Nigeria". 2008. Journal of Environmental Hydrology., Vol. 16.

[8] Arvnabh, M., Vasishta, D., Bhatt, N. S., Pinal, S., Kirit, P., Chaitanya P., "Comparative study of physicochemical and microbial paramters on Lotic and Ground-Waters in selected outlaying areas of Central Guijarat". 2010. J. Chem. Pharm. Res., Vol. 2, pp. 174177.

[9] Soladoye, O., Ajibade, L. T., "A groudwater quality study of Lagos State, Nigeria". 2014. International Journal of Applied Science and Technology, Vol. 4, pp. 271-281.

[10] Olowu, I., "Reports of water quality from hand-dug wells in some parts of Lagos State". 2019. Unpublished.

[11] Water quality of Ajasa Ipaja, Lagos State. Lagos State Water Corporation. 2019.

[12] Chenchouni, H., "Diagnostic Ecologique d'Un aite propose ramsar:Chott de Djendli (Batna-Alagerie)". Algeria: University of Batna, 2007. Engineer Dissertation.

[13] Aliat, T., Kaabeche, M., Khomri, H., Nouri, L., Neffar, S., Chenchouni, H., "A pedological characterisation of some inland wetlands and Ramsar sites in Algeria". 2016. Land Degradation Dev., Vol. 27, pp. 693-705.

[14] Raja, R. E., Lydia, S., Princy, M., Chritopher, G., "Physico-Chemical Analysis of Some Groundwater Samples of Kotputli Town Jaipur, Rajasthan". 2002. Indian J Environ Prot,, Vol. 22, p. 137.

[15] Jozef, Z., Tomasz, B., "Impact of cemeteries on groudwater contamination by bacteria and viruses _ a review". 2015. Journal of water and health, Vol. 13, pp. 285-301.

[16] Matos, B. A., "Occurrence and transport of microorganisms in groundwater acquifer of Vila Nova Cachoeirinha cemetery, Municipio de Sao Paulo". Dissetation, Institutio de Geociencias da Universidade de Sao Paulo, 2001.

[17] Espindula, J. C., Santos, A. C., "Hydrogeological 
characteristics and vulnerability of shallow aquifer in the cemetery of the Várzea Recife/PE. ABAS, São Paulo". XIII Brazilian Congress on Groundwater, 2004. pp. 1-9.

[18] Abrão, M. E. A., "Evaluation of Contamination Underground Water from Cemeteries: the Case of Santo Amaro Cemetery in Campo Grande, Campo Grande". Dissertation, Universidade Federal de Mato Grosso do Sul, 2007.

[19] Omole, D. O., "Sustainable groundwater exploitation in Nigeria". 2013. Journal of Water Resources and Ocean Science, Vol. 2, pp. 9-14.

[20] Cadmium. US Environmental Protection Agency Office of Drinking Water health advisories. Ware GW. 1989. Reviews of Environmental Contamination and Toxicology, Vol. 107, pp. 25-37.

[21] Standard methods for examination of waters and waste waters. 16th. New York, 1205 : APHA, AWWA and WPCF Inc, 1985.

[22] Ouma, S. O., Ngeranwa, J. N., Juma, K. K., Mburu, D. N., "Seasonal variation of the physicochemical and bacteriological quality of water from five rural catchment areas of Lake Victoria basin in Kenya". 2016. J. Environ. Anal Chem, Vol. 3, p. 170. doi:10.41722380-2391.1000170.

[23] Kobielska, P. A., Howarth, A. J., Farha, O. K., Nayak, S., "Metal-organic frameworks for heavy metal removal from water. 2018. Coord. Chem. Rev., Vol. 358, pp. 92-107.

[24] Delgado, J. M. P. Q., Guimaraes, A. S., de Freitas, V. P., Antepara, I., Koci, V., Cerny, R., "Salt Damage and Rising Damp Treatment in Building Structures". Hindawi Publishing Corporation, 2016. Advances in Materials Science and Engineering.

[25] Maas, E. V., Grattan, S. R., "Crop yields as affected by salinity". 1999. American Society of Agronomy.

[26] Katergi, N., Van Hoorn, J. W., Hamdy, A., Mastrorilli, M., "Salt tolerance classification of crops according to soil salinity and to water stress day index". 2000. Agricultural water management, Vol. 43, pp. 99-109.

[27] Elemile, O. O., Raphael, D. O., Omole, D. O., Oloruntoba, E. O., Ajayi, E. O., Ohwavboru, N. A., "Assessment of the impact of abattoir effluent on the quality of underground water in a residential area of Omu-Aran, Nigeria". 2019. Environ Sci Europe.

[28] Spongberg, A. L., Becks, P. M., "Inorganic soil contamination from cemetery leachate". 2000. Water Air Soil Pollut, Vol. 117, pp. 313-327.

[29] Jonker, C., Olivier, J., "Mineral contamination from cemetery soils: Case study of Zandfontein Cemetery, South Africa". 2012. Int'l J. Environ. Res. Pblic Health, Vol. 9, pp. 511-520.

[30] Schock, M. R., "Causes of temporal variability of lead in domestic plumbing systems". 1990. Environmental monitoring and assessment, Vol. 15.

[31] Landmeyer, J. E., Bradley, P. M., Bullen, T. D., "Stable lead isotopes reveal a natural source of high lead concentrations to gasoline-contaminated groundwater". 2003. Environmental Geology, Vol. 45, pp. 12-22.

[32] Nduka, J. K. C., Orisakwe, O. E., "Heavy Metal Levels and Physico - Chemical Quality of Potable Water Supply in Warri, Nigeria". 2007.

[33] Cadmium in drinking water: Background document for development of . WHO. 2011, WHO Guidelines for drinking water.

[34] Gerba, C. P., Bitton, G., "Microbial pollutants: their survival and transport pattern to groundwater". 1984. Groundwater Pollution Microbiology, pp. 65-88.

[35] De Ville de Goyet C., "Infectious diseases and epidemiological survellance in situations of natural disaters". 1980. Bol. Oficina San it Panam, Vol. 89, pp. 353-359.

[36] Rodriguez, L., Pacheco, A., "Groundwater contamination from cemeteries cases of study. University of Porto, Porto". 2010. International symposium: Environment. pp. 1-6.

[37] Pedley, S., Guy, H., "The public healyth implications of microbial contamination of groundwater". 1996. Q. J. Eng. Geol., Vol. 30, pp. 179-188.

[38] Josias, A., Harris, K., "Protecting groundwater from contamination". Pretoria : DWAF, 2004.

[39] Oliveira, W., Tagliarini, E. M., Tancredi, A. C. F. N. S., "Hydrogeological study for implementation of the Max II cemetery _ Region of Belem-Para. ABAS, Sao Paulo". XII Brazilian Congress on groudwater, 2002. pp. 1-12.

[40] Mello, F. S., Motidome, M. J., Magalhaes, F. S. P., "Do cemeteries pollute"? 1995. Revista Saneamento Ambiental, Vol. 6, pp. 44-45.

[41] Abia, A. L. K., Alisoltani, A., Ubomba-Jaswa, E., Dippenaar, M. A., "Microbial life beyond the grave: $16 \mathrm{~S}$ rRNA gene-based metagenomic analysis of bacteria diversity and their functional profiles in cemetery environments". 2018. Sci Total Environ, pp. 831-841.

[42] Alison, L., Spongberg, P. M., "Inorganic soil contamination from cemetery leachate". 2000. Water, Air and Soil Pollution, Vol. 117, pp. 313-327.

[43] Parihar, S. S., Kumar, A., Kumar, A., Gupta, R. N., Pathak, M., Shrivasta, A., Pandey, A.C., "PhysicoChemical and Microbiological Analysis of Underground Waterin and around Gwalior City, MP, India". 2012. Research Journal of recent Sciences, Vol. 16, pp. 62-65.

[44] Ahmet, S., Ucisik, P. R., "The impact of cemeteries on the environment and public health: An introductory 
International Journal of Engineering Research and Technology. ISSN 0974-3154, Volume 13, Number 6 (2020), pp. 1283-1288

(C) International Research Publication House. https://dx.doi.org/10.37624/IJERT/13.6.2020.1283-1288

briefing". Target 23: Waste management and soil pollution. 1998.

[45] Ayeni, A. O., Oyekunle, D. T., Adegbite, O., Alagbe, E., Ejekwu, O., "Physico-chemical remediation of polycyclic aromatic hydrocarbons contaminated soil". 2019. Journal of Physics, Conference Series, Vol. 1299.

[46] Bauder, T. A., Waskom, R. M., Sutherland, P. L., Davis, J. G., "Irrigation water quality criteria". Colorado State University. Crop Series Fact Sheet 0.506 .

\section{APPENDIX}

Table 3: Approximate distance between points.

\begin{tabular}{|l|l|}
\hline Points & Distance, $\mathrm{m}$ \\
\hline $1-2$ & 178.61 \\
\hline $2-3$ & 44.25 \\
\hline $3-4$ & 78.04 \\
\hline $4-5$ & 88.17 \\
\hline $5-6$ & 48.59 \\
\hline $6-7$ & 270.01 \\
\hline $7-8$ & 101.76 \\
\hline $8-9$ & 188.26 \\
\hline $9-10$ & 91.77 \\
\hline $1-10$ & 529.10 \\
\hline
\end{tabular}

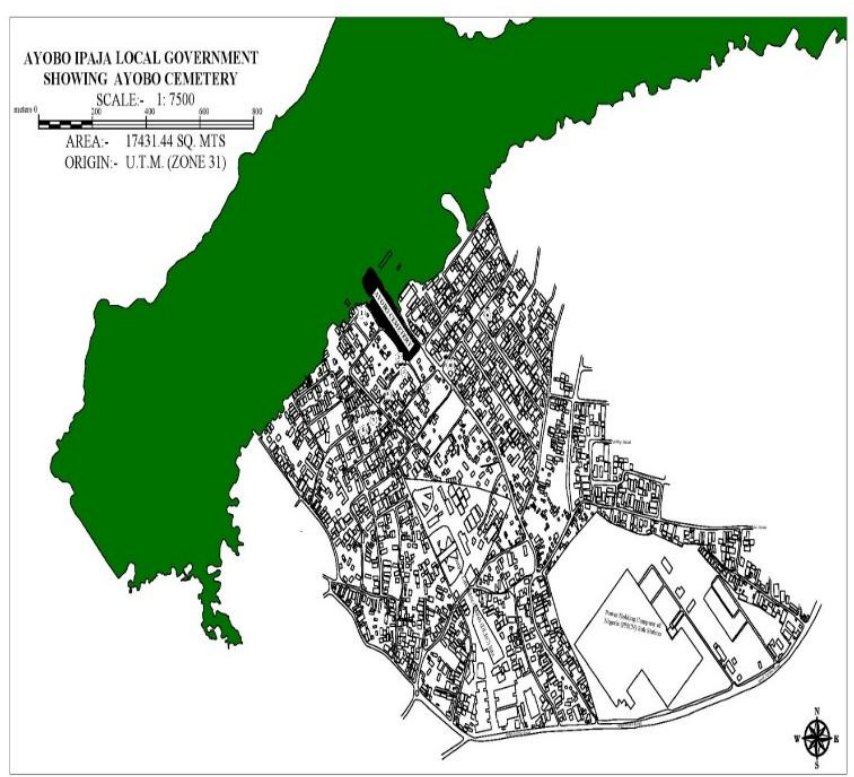

Fig. 1: Map showing Ayobo cemetery and its environs (with the collection points). 